Instructions for authors, subscriptions and further details:

http://rasp.hipatiapress.com

\title{
Tan Frescas. Las Nuevas Mujeres Mayores del Siglo XXI
}

Begoña García-Pastor ${ }^{1}$

1) UNED - Universitat Jaume I

Date of publication: July $30^{\text {th }}, 2015$

Edition period: July 2015 - January 2016

To cite this review: García-Pastor, B. (2015). Tan Frescas. Las Nuevas Mujeres Mayores del Siglo XXI [Review of the book]. Research on Ageing and Social Policy, 3(1), 85-87. doi: 10.17583/rasp.2015.1547

To link this review: http://doi.org/10.17583/rasp.2015.1547

\section{PLEASE SCROLL DOWN FOR ARTICLE}

The terms and conditions of use are related to the Open Journal System and to Creative Commons Attribution License (CCAL). 
RASP - Research on Ageing and Social Policy Vol. 3 No. 1

July 2015 pp. 85-87

\section{Review}

Freixas Farré, Anna (2013). Tan Frescas. Las Nuevas Mujeres Mayores del Siglo XXI. Madrid: Paidós.

$\neg$ ras una intensa trayectoria académica e intelectual preocupada por la vejez como futuro psicosocial que llega a todas las mujeres, Tan frescas. Las nuevas mujeres mayores del siglo XXI nos ofrece una reflexión crítica y muy amplia sobre la construcción de la vejez y la vivencia femenina de los procesos de envejecimiento. Un libro feminista, escrito con complicidad y sentido del humor, que constituye una revelación sincera de la experiencia, del modo de pensar y de ver las cosas de su autora. Ante una temática tan compleja como es el fenómeno de la vejez, Anna Freixas Farré sobrepasa el ámbito académico, adentrándose en la sabiduría que genera la vida real de las mujeres y en su propia cotidianeidad, para explicar y echar luz sobre aspectos de la vejez silenciados y considerados corrientemente muy oscuros. De ese modo, además de atrayente y divertida, la lectura de este libro resulta sin duda útil para comprender mejor y afrontar, con más empatía y menos miedos, el proceso biológico y social de envejecer que todas y todos experimentamos desde el mismo nacimiento.

Como ya se anuncia en el título, el interés de la autora se centra especialmente en dar a conocer las vivencias múltiples de las mujeres mayores del siglo XXI, a quienes nos presenta como personas luchadoras que, a menudo, se consideran cómplices en la promoción de transformaciones políticas y mejoras sociales a las que no hay porqué renunciar por dejar de ser jóvenes. Con enfoque atento y decididamente crítico, el texto profundiza en el llamado "edadismo", analizándolo como un problema de

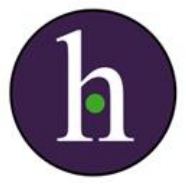




\section{Begoña García-Pastor - Tan Frescas}

justicia e igualdad social que acecha a todo el mundo y, en particular, a las mujeres. Junto a las desigualdades que son fruto del machismo "tradicional", Freixas aborda esas otras formas de marginación y exclusión social que se acaban legitimando por razón de edad. A su juicio, aunque parezca que despierten menos interés o preocupación social, nos encontramos ante actitudes y comportamientos injustos que interaccionan con el sexismo y es necesario entender, para poderlos deslegitimar y superar.

El texto lanza con valentía opiniones transgresoras y reivindicativas acerca de las imágenes de la vejez y las personas mayores que reinan en nuestra sociedad, denunciando los intereses económicos, y también políticos, que subyacen al mercado de productos cosméticos y farmacológicos, invadido de asociaciones que identifican machaconamente el envejecimiento con los achaques, la decrepitud y la fealdad. Desde posicionamientos teóricos feministas, Freixas comparte su visión contraria y mucho más optimista de que "otra vejez es posible". Con dosis justa de frescura y realismo, su análisis cuestiona ese imaginario social negativo que rodea a la vejez, donde, por cierto, también aclara que acaban pagando y perdiendo más las mujeres que los hombres. Mostrando otras caras amables y envidiables de las consecuencias múltiples que el paso del tiempo suele tener para ellas, por ejemplo, el aumento de la confianza en una misma y de la autoestima, un enfoque más realista y compasivo sobre las personas, mayor capacidad para relativizar, gestionar, elegir con libertad..., el texto que nos ocupa contribuye a la des-estigmatización de la vejez. Aporta, de hecho, interesantes claves de reflexión para deconstruir y abandonar muchos de los prejuicios que, condicionando consciente o inconscientemente nuestras relaciones sociales, sufrimos la mayoría de las mujeres cuando nos hacemos mayores.

En el terreno de la sexualidad, sus reflexiones son especialmente críticas, al destapar de manera rotunda el androcentrismo con que se abordan cotidianamente, y en concreto en la última etapa de la vida, los aspectos múltiples relacionados con la vejez y el envejecimiento: el cuerpo, la belleza, el amor, el deseo, las costumbres, la moral... Sus opiniones sobre la vivencia y la práctica de la sexualidad en el caso de las mujeres mayores van más allá de las perspectivas biologicistas desde las que, demasiado a menudo, se pretende explicar la disminución del deseo y de las relaciones sexuales, la tendencia al celibato... Desde su punto de vista, tales procesos 
pueden estar más relacionados con aspectos sociales, culturales y morales: parejas de larga duración, la falta de pareja y de aceptación del sexo esporádico, creencias personales sobre la menopausia como "el principio del fin", las expectativas culturales que niegan, censuran y ridiculizan la sexualidad en la vejez, negación de la pluralidad y alternativas sexuales.... Para Freixas, las dificultades que las mujeres experimentan en la vejez, en este terreno personal y relacional, son multifactoriales y tienen mucho que ver las vivencias que se han tenido en las etapas anteriores y con la educación. Su examen de las imágenes y de los significados de la sexualidad de las nuevas mujeres mayores del siglo XXI parte de una visión feminista que logra superar definitivamente las limitaciones impuestas por la heterosexualidad normativa, incluyendo las experiencias de las mujeres lesbianas como un buen ejemplo de lucha contra prejuicios y dificultades.

Por todo lo anterior, la lectura de Tan Frescas resulta, además de entretenida, muy interesante para todos los públicos. Estamos ante un texto fresco, con una temática que concierne a todo el mundo y un enfoque que abre caminos nuevos de empatía, comprensión y solidaridad intergeneracional que son sin duda necesarios.

Begoña García-Pastor, UNED - Universitat Jaume I bgarcia@uji.es 